\title{
Familial Breast Cancer in Costa Rica: An Initial Approach
}

\author{
Adriana Ramírez Monge ${ }^{2}$, Gustavo A. Gutiérrez-Espeleta ${ }^{1,2}$ \& Kenneth Loáiciga Vega ${ }^{3}$ \\ 1 Escuela de Biología, Universidad de Costa Rica \\ 2 Instituto de Investigaciones en Salud, Universidad de Costa Rica \\ 3 Hospital San Juan de Dios, San José, Costa Rica
}

Received 22-III-2004. Corrected 10-VIII-2004 Accepted 24-VIII-2004.

\begin{abstract}
Cancer is a worldwide problem because of its high rates of incidence and associated mortality. By 2000, more than 6.2 million people died from this illness worldwide. Among all types of cancer, breast cancer is one of the most studied. Each year, one million new cases are diagnosed around the world. We can classify breast cancer into two main kinds: sporadic cases and those which are a product of inherited genetic alterations. Approximately $5-10 \%$ of breast cancer cases are the result of inherited mutations, or alterations in breast cancer susceptibility genes, BRCA1 and BRCA2. Like other countries, Costa Rica possesses high rates of incidence and mortality for breast cancer. According to the "Registro Nacional de Tumores" (National Office of Tumor Records), in 2000 breast cancer had the highest rate of incidence and in 2002 it had the highest rate of mortality in comparison to other types of cancer. For this reason and the generalized lack of knowledge in the field we conducted an epidemiological research on breast cancer patients from Hospital San Juan de Dios, San José, Costa Rica, to find families with a history of breast cancer, and to determine the occurrence of familial cases within the population studied. So far, we have found 23 families, within which we discovered very informative cases that have rendered the identification of a pattern of inheritance. These findings allow us to announce that in Costa Rica there are several cases of inherited breast cancer and that we need more research is needed to improve the prevention, control, and treatment of this disease. Rev. Biol. Trop. 52(3): 531-536. Epub 2004 Dic 15.
\end{abstract}

Key words: breast cancer, incidence, mortality, epidemiology, Costa Rica.

Palabras clave: Cáncer de mama, incidencia, mortalidad, epidemiología, Costa Rica.

In general terms, cancer is a group of diseases whose main characteristic is the uncontrolled growth and spread of cells. Cancer could be caused by two types of factors: external factors like infectious organisms and internal factors like mutations or changes in DNA sequence (Anonymous 2003).

Cancer is a worldwide problem because of its high rates of incidence and mortality. According to the cancer report published last year by the World Health Organization (WHO), in 2000 malignant tumors represented $12 \%$ of the 56 million deaths for all kind of causes worldwide, this means that 6.2 million people died of cancer (Anonymous 2003). Likewise, the American Cancer Society pre- dicts about 1368030 new cancer cases to be diagnosed in 2004 and they expect 563700 deaths caused by cancer just in the United States, which implies that more than 1500 people are going to die daily for any given kind of cancer (Anonymous 2003).

Breast cancer is one of the cancer types that has been studied more because of its alarming incidence and mortality rates. More than one million new cases are diagnosed in the world each year, making this kind of cancer occupy a leading position in terms of incidence and mortality rates around the world. Furthermore, in some countries like the United Kingdom, breast cancer is the most common cause of death among women (McPherson 2000, Ruiz et al. 2002). 
Breast cancer is a complex disease that begins in the breast tissue, which is primarily made up of glands and fatty, connective, and lymphatic tissue (Friedewald et al. 1997, Anonymous 2003).

Tumors could be localized, or in situ (because they have not yet spread beyond the area where they began), invasive, or infiltrating (when they invade the surrounding tissues) (Friedwald et al. 1997, Chen et al. 2002, Anonymous 2003). They could also be classified in different stages based on their size and the presence or absence of metastasis. These stages go from 0 to IV, the latest being when cancer has metastasized to other organs (Friedwald et al. 1997, Aguilar 1999, Anonymous 2004).

Breast cancer can be classified into two main kinds of cases: sporadic cases and those which are product of inherited genetic alterations mainly in two genes, BRCA1 and BRCA2. (Harber and Fearon 1998, Marquez and Trujillo 1999, Lawrence et al. 2001, Peterson 2002). When comparing the inherited cases of breast cancer to the sporadic cases certain differences arise: in inherited cases, the onset happens earlier, women under 20 years of age could be diagnosed, the prevalence of bilateral cases (both breasts) is higher, and related tumors could appear in some members of the same family (Márquez and Trujillo 1999). Another important aspect related to this type of breast cancer is that in certain families, apart from multiple cases of breast cancer, some families also have multiple cases of ovarian cancer and prostate cancer. This is because BRCA1 and BRCA2 are also susceptibility genes for these two types of cancer, so people who have a family history of breast cancer have a higher risk of developing these diseases.

The cases due to hereditary predisposition are transmitted as an autosomal dominant trait with limited penetrance (Breast Cancer Linkage Consortium 1997, McPherson 2000). This means that it can be transmitted through either sex and some family members could be carriers of the abnormal gene, without developing the illness themselves, but also they may transmit the mutations to the next generations (McPherson 2000).

The susceptibility gene BRCA1 seems to be responsible for $45 \%$ of the cases in families with multiple cases of breast cancer and responsible for the $90 \%$ of the cases when the family presented multiple cases of both breast and ovarian cancer (Easton et al.1995). On the other hand, the susceptibility gene BRCA2 seems to be responsible for $35 \%$ of the cases in families of multiple cases but is also the most common affected gene in studied families that present cases of male breast cancer and prostate cancer (Wooster et al. 1994).

The mutations in those genes account for a proportion of breast cancer cases, as well as some ovarian and prostate cancer. From all the cases that have been diagnosed in the population, approximately $5-10 \%$ of breast cancer cases are the result of inherited mutations, or alterations in breast cancer susceptibility genes (BRCA1 and BRCA2) (Harber and Fearon 1998, Marquez and Trujillo 1999, Lawrence et al. 2001).

The American Cancer Society calculates 215990 new cases of breast cancer occurring among women in 2004, and estimates 40580 deaths due to breast cancer within the population of the Unites States. Based on this calculation, between 10799 and 21599 people in the United States are going to develop breast cancer because of an inherited mutation on their susceptibility genes. Of these, around 4058 persons are going to die from breast cancer (Anonymous 2003, Anonymous 2004). In addition, this type of cancer is the second cause of death for women in Europe. In Spain, approximately 13500 new cases are diagnosed and 5900 people die each year. This means that approximately 1350 people develop breast cancer in that country because of their family history each year (Llort et al. 2002, Hadjisavvas et al. 2003).

Like other countries, Costa Rica possesses high rates of incidence and mortality for breast cancer (Sierra et al. 1995, Bartels et al. 1999). According to the "Registro Nacional de 
Tumores" (National Office of Tumor Records), for the year 2000 breast cancer had the highest rate of incidence (37.8 new cases for each 100000 women) in comparison with other cancer types, e.g. in the uterus (7.2) and stomach (18.6). For 2002, breast cancer had the highest mortality rate (11.6 deaths for each 100 000 women) among all types of cancer that affected women in the country. This kind of cancer occupies the first place for both incidence and mortality in Costa Rica (Registro Nacional de Tumores, unpublished data).

In Costa Rica the only information available are the records of incidence and mortality that the "Registro Nacional de Tumores" (National Office of Tumor Records) maintains, there is no more information about breast cancer. The percentage of inherited breast cancer cases is unknown so far, given that no research has been made to determine the magnitude of the problem in our country.

Because of this lack of information, Costa Rica's health system does not have adequate policies to handle patients with inherited breast cancer properly, because traditional diagnose methods like mammography are not the best suited for these women.

For this reason, we conducted a six month epidemiological research on breast cancer patients who came to Hospital San Juan de
Dios (Class A hospital), for a medical check up. The objective was to find familial cases of breast cancer. To include a family in this project we used the next criteria: at least three individuals of the maternal or paternal side of the family who had been diagnosed with breast cancer by biopsy at an early age (before the age of fifty) each family should have at least three cases of female breast cancer, ovarian cancer, male breast cancer or prostate cancer; at least two of the affected members of the family have to be first degree relatives.

To we have found 23 families. A total of 81 individuals had breast cancer and 22 of these had died because of the illness. We discovered very informative cases (3-11 affected people with breast cancer in the same family) that have rendered the identification of a pattern of inheritance, which is consistent with the autosomal dominant inheritance (Fig. 1). We also found five cases of prostate cancer in three families (Fig. 2), and one case of ovarian cancer in one family. All these families also presented multiple cases of breast cancer. The ovarian and prostate cancer cases could be related to the same alterations in the BRCA1 and BRCA2 genes in all these families.

If we compare our findings with studies from other countries we can affirm that they are important. For example, in a research conducted

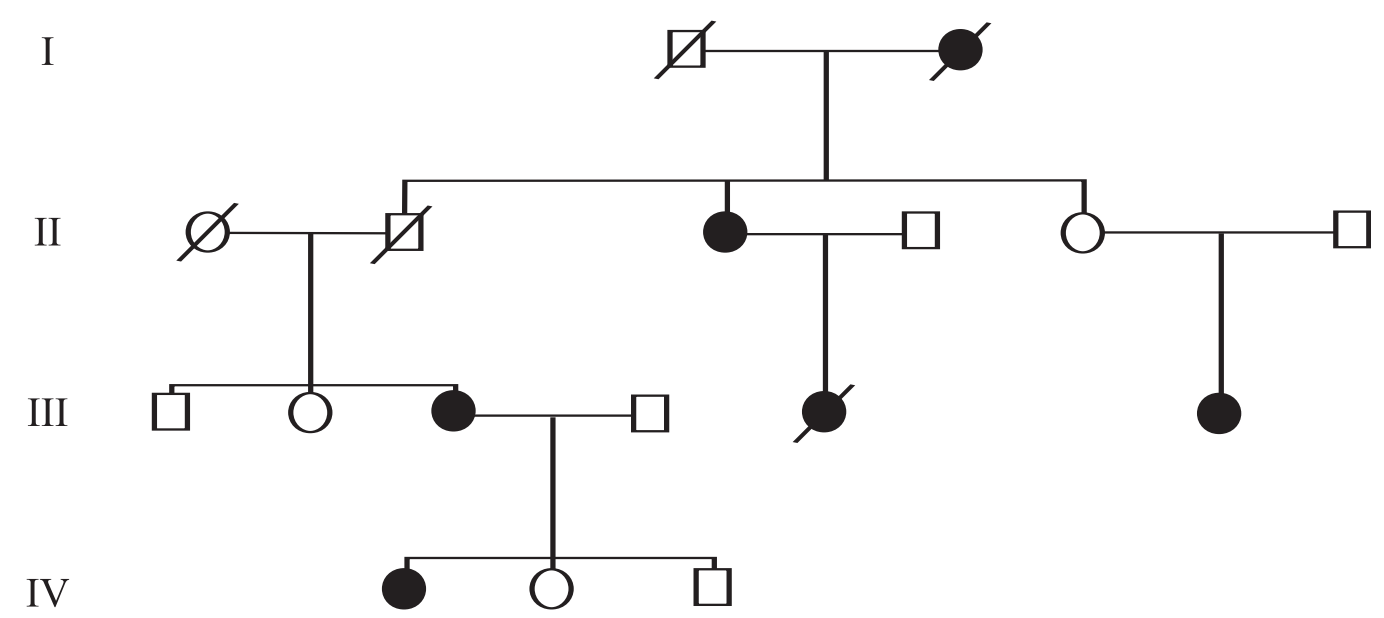

Fig. 1. Pedigree of a family with multiple cases of breast cancer $(\bullet)$ that shows a pattern of autosomal dominant inheritance. 


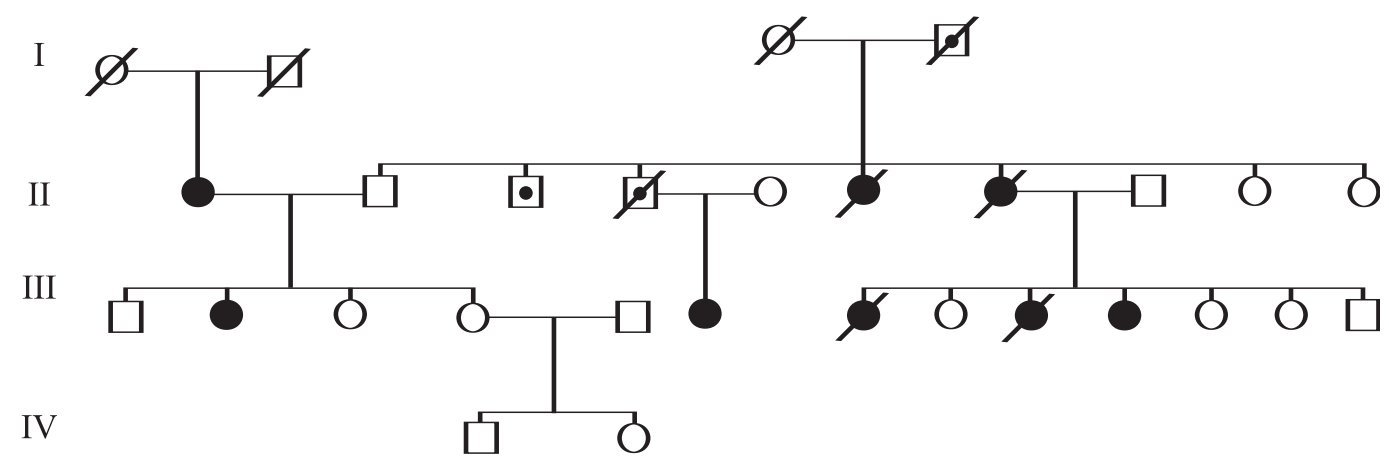

Fig. 2. Pedigree of a family that presents multiple cases of breast cancer

) and several cases of prostate cancer $(\bullet)$

by Ruiz-Flores et al. (2002) in Mexico they included just 51 patients of breast cancer identified through the clinical records of the "Hospital Universitario" (6 years and three months of study) and the "Clínica 25, Instituto Mexicano del Seguro Social" (one year and three months of study) both in Monterrey. As in our research, they found families with more than one cancer type, for example, they found two families with both breast and ovarian cancer, and also these families have an extensive family history of other cancer types like lung cancer. Furthermore, they found one family with female and male breast cancer. In our study we did not find male breast cancer.

It is important to clarify that our results are not a product of an exhaustive research throughout the country. It is just a preliminary study that tells us that hereditary breast cancer incidence could be more serious than what we thought and that it is extremely important to conduct a similar study at the national level to determine the percentage of breast cancer cases that are the result of alterations in both susceptibility genes BRCA1 and BRCA2.

With all this information, we will have the possibility to develop different kinds of molecular techniques to diagnose breast cancer, aimed at finding mutations mainly in those two genes. The information obtained from genetic testing may enable women to make more informed decisions about their medical management, which includes prevention, control, and treatment. According to Lawrence et al. (2001), women who test positive for BRCA1 or BRCA2 mutations have several options for cancer risk reductions.

In conclusion, alterations in the breast cancer genes are associated with an increased risk of breast, ovarian, and prostate cancers. The potential methods to identify mutations in breast cancer genes give us the opportunity to check for carriers of such mutations at an early age. We do not know which carriers are at highest risk, because there is no knowledge on what factors modify cancer risk (other genes or environmental factors could be involved). However, if we make the right decision at the right time, we could reduce the incidence and mortality rates for this type of cancer.

We are in the process of developing a follow-up study in these patients with an option to be tested for mutations in breast cancer genes. We are also trying to determine risk factors, in addition to these mutations, that may modify a person's chance of developing breast, ovarian, or prostate cancer.

\section{ACKNOWLEDGMENTS}

We thank the patients of the San Juan de Dios Hospital who participated in the study. We also thank Jeffry Ortiz and Francisco Calvo for their help. 


\section{RESUMEN}

El cáncer es un problema a nivel mundial porque posee altas tasas de incidencia y mortalidad. Para el año 2000 más de 6.2 millones de personas murieron a causa de esta enfermedad. El cáncer de mama es uno de los tipos de cáncer más estudiados en el mundo por las mismas razones. Cada año, se diagnostican más de un millón de casos nuevos de cáncer de mama alrededor del mundo. Podemos clasificar al cáncer de mama en dos tipos principales: los casos esporádicos y los que son producto de alteraciones genéticas heredables. De todos los casos que son diagnosticados en la población, aproximadamente de un 5 a un 10 $\%$ son resultado de mutaciones heredadas o alteraciones en los genes de susceptibilidad BRCA1 y BRCA2. Como en otros países, Costa Rica posee altas tasas de incidencia y mortalidad para el cáncer de mama. Según el Registro Nacional de Tumores para el año 2000 el cáncer de mama tuvo la tasa de incidencia más alta y para el 2002 alcanzó la tasa de mortalidad más alta en comparación con otros tipos de cáncer. Por esta razón y por la falta de conocimiento existente decidimos realizar un estudio epidemiológico de los pacientes con cáncer de mama del Hospital San Juan de Dios para encontrar familias con un historial de cáncer de mama y determinar la existencia de casos de cáncer de mama familiares en esta población. Hemos encontrado 23 familias dentro de las cuales hayamos casos informativos que nos han permitido identificar un patrón de herencia. Estos hallazgos nos permiten afirmar que en Costa Rica se dan casos de cáncer de mama heredados y que necesitamos más investigación para mejorar el tratamiento de los pacientes que sufren de cáncer de mama.

\section{REFERENCES}

Anonymous. 2003. Breast Cancer Facts and Figures 20032004. American Cancer Society. 23 p. (Also available online: http://www.cancer.gov)

Anonymous. 2004. Cancer Facts and Figures 2004. American Cancer Society. 56 p. (Also available online: http://www.cancer.gov)

Aguilar, M. 1999. Manejo de los estadíos I y II del cáncer de mama entre los años 1990-1998 en el servicio de oncología del hospital San Juan de Dios. Tesis de Licenciatura. Universidad de Costa Rica. San José, Costa Rica. 39 p.

Bartels Rodríguez, R., R.M. Vargas \& G. Muñoz. 1999. Incidencia y mortalidad del cáncer en Costa Rica 1994/1996. Ministerio de Salud, San José, Costa Rica. 200 p.

Chen, C., N. Weiss, P. Newcomb, W. Barlow \& E. White. 2002. Hormone replacement therapy in relation to breast cancer. JAMA 287: 734-741.
Eastson, D.F., D. Ford, T. Bishop \& Breast Cancer Linkage Consortium. 1995. Breast and ovarian cancer incidence in BRCA1-mutations carriers. Am. J. Hum. Genet. 56: 256-271.

Friedwald., V., A. Buzdar \& M. BoKulich. 1997. Cáncer de seno todo lo que usted debe saber. Grupo editorial Norma, Bogotá, Colombia. 158 p.

Haber, D. \& E. Fearon. 1998. The promise of cancer genetics. Lancet 351: 1-8.

Hadjisavvas, A., E. Charalambous, A. Adamou, C. Chistodolou \& K. Kyriacou. 2003. BRCA2 Germline mutations in Cypriot patients with familial Breast/Ovarian Cancer. Hum. Mut. 21: 171-175.

Lawrence, W., B. Peshkin, W. Liang, C. Isaacs, C. Lerman \& J. Mandelblatt. 2001. Cost of Genetic counseling for BRCA1 and BRCA2 Breast cancer susceptibility Mutations. Can. Epidemiol. Biomak. Prev. 10: 475-481.

Llort, G., C. Yagüe, M. Peris, G. Blanco, J. Dermà, A Bale \& M. Alvarez. 2002. Low frequency or recurrent BRCA1 and BRCA2 Mutation in Spain. Hum. Mut. 19: 307-313.

McPhearson, K., C. Steel \& J. Dixon. 2000. Breast cancerepidemiology, risk factors and genetics. Brit. Med. J. 321: 624-628.

Peterson, E., K. Milliron, K. Lewis, S. Goold \& S. Merajver. 2002. Health insurance and discrimination concerns and BRCA1/2 in a clinic population. Can. Epidemiol. Biomak. Prev. 11: 79-87.

Ruiz, P., O. Sinilnikova, M. Badzioch, A. Calderon, S. Chopin, O. Fabrice, J. Gonzáles, C. Szabo, G. Lenoir, D. Goldgar \& H. Barrera. 2002. BRCA1 and BRCA2 Mutation Analysis of Early onset and familial breast cancer cases in Mexico. Hum. Mut. 20: 474-480.

Sierra, R., L. Rosero-Bixby, D. Antich \& G. Muñoz. 1995. Cáncer en Costa Rica: Epidemiología Descriptiva. Universidad de Costa Rica, San José, Costa Rica. 87 p.

Wooster R., S. Neuhausen \& J. Mangion. 1994. Localization of breast cancer susceptibility gene, BRCA2, to chromosome 13q12-13. Science 256: 2088-2092.

\section{INTERNET REFERENCES}

Anonymous, 2003. Global cancer rates could increase by $50 \%$ to 15 million by 2020. World Health Organization. 7 p. (Downloaded: February 04, 2004. http://www.who.com). 
Márquez A. \& R. Trujillo 1999 Cáncer de mama hereditario (I). MEDSPAIN. La nueva revista de Medicina y Salud en Internet (Downloaded: January 22, 2002. http://www.medspain.com/n6_nov99/cancer_mama 1.htm).
Márquez A. \& R. Trujillo 1999 Cáncer de mama hereditario (II). MEDSPAIN. La nueva revista de Medicina y Salud en Internet (Downloaded: January 22, 2002. http://www.medspain.com/n7_nov99/cancer_mama 2.htm). 